\title{
Reviews
}

\section{Out of the Woods: A Journey Through Depression and Anxiety}

By Brent Williams, with illustrations by Korkut Öztekin Educational Resources. 2017. £19.95 (hb). 160 pp. ISBN 9780473390068

This is an insightful and extremely valuable book depicting a man's journey through depression and anxiety. It is based on Brent Williams' experiences and is a deeply personal account, but is also based on sound medical science. Williams' personal experiences and the unusual graphic novel format make the book very accessible, allowing the reader to understand the experience of depression and anxiety. It is beautifully illustrated by Korkut Öztekin, with pictures which often 'say' so much more than words in terms of evoking the atmosphere and man's mood.

We journey with the man from a period of deep depression to recovery, passing through multiple steps on the wayincluding trying to recover alone, resisting help and later becoming open to help. The book offers an explanation as to how and why one might be feeling depressed and anxious, as well as enabling the reader to learn about the symptoms of depression and anxiety.

Importantly, the story shows the reader how to take the steps towards recovery. The man is told, '[y]ou need to break the downward spiral ... by doing lots of small and manageable things'. The reader is exposed to breathing techniques, mindfulness and the importance of nature, learning, human contact and exercise amongst other practical steps which help promote recovery.

The book also demonstrates a realistic recovery path with the ups and downs which are so typical. Most significantly, by charting the man's recovery it offers hope and demonstrates a way forward which will be helpful and comforting to those with similar problems. There are elements of the narrative which are perhaps a little alien to the National Health Service culture. Nevertheless, this is a much-needed book which will be very useful to patients and their families/friends as well as a great help to general practitioners by supporting the messages we give.

Rebecca Smith, Pallant Medical Chambers West Kent, Forum House, Stirling Road, Chichester, West Sussex, P019 7DN, UK. Email: rebecca.smith103@nhs.net

\section{doi:10.1192/bjb.2018.104}

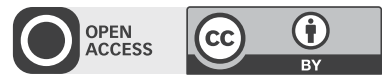

(c) The Author 2019. This is an Open Access article, distributed under the terms of the Creative Commons Attribution licence (http://creativecommons.org/ licenses/by/4.0/), which permits unrestricted re-use, distribution, and reproduction in any medium, provided the original work is properly cited.

\section{Outside the Asylum: A Memoir of War, Disaster and Humanitarian Psychiatry}

By Lynne Jones

W\&N. 2018. 368 pp. $€ 9.99$ (pb). ISBN: 9781474605748

Lynne Jones has spent much of the last two decades setting up and running mental health programmes in places devastated by natural disasters and wars. Jones is a child psychiatrist, who began her career in the Allinton Psychiatric Hospital, the former Allinton Asylum. From the off, she cared more about pragmatic pacifism and 'doing the right thing', which included a commitment to living by her values of public service and altruism. She has a CV 'full of gaps': when she was at Greenham Common, Bosnia, on the Somali border in Ethiopia, in Kosovo, Ethiopia, Haiti, Tacloban, and many other places where bombs have fallen or tsunami have washed away communities. Jones says her mother thinks she is on 'an extended gap year'.

Her memoir has been compared to the writing of Oliver Sacks, which I think does them both a disservice. Jones' style and approach are different to Sack's pen portraits of neurological conundrum, although she does interlace clinical stories through her accounts. Her reminiscences of being with asylum patients on the dance floor evoke the recent work of Dr Charlie Howard, whose Music and Change project engages with teenage gangs at street level, co-producing models of care delivery.

Professionally, there is much to admire here, not least Jones' commitment to academic rigor despite being far from university departments. For instance, she describes staying on in Bosnia for an additional year after her contract had ended to study the effects of war on children. Her contributions to the intellectual, cultural and academic life in the countries she is sent to are similarly admirably. These exchanges are two-way: by spending time with communities and by listening to young people, Jones provides solutions that work for them and their families. She wears diverse theoretical cloaks lightly, using combinations of systemic family therapy, medication, group therapy and supportive counselling. Her stance is pragmatic, for example commencing a young man on medication earlier than she would like so that she can monitor the effects before her likely evacuation from the country.

Jones writes without bitterness or naïvety, recognising that, as a humanitarian worker, she is sometimes a pawn in political game, for example when she is part of a wider evacuation of international aid workers and has to say hurried farewells to unwell patients and local colleagues. There must surely have been times when Jones was fatigued, professionally isolated, personally lonely. We don't hear about it. But though she is stoic, she is also angry, especially about the 
pseudoscience that underpins the trauma industry and the resultant thoughtless 'quick-fixes' from many who ought to know better

The atrocities she describes are apocalyptic in both scale and terror. In them, she endures personal hardships: living without running water, without electricity, yet aware of her privileged status, her passport, her choice to be there, her safe home in the UK. Jones is repeatedly drawn back to disaster scenes, not because of their horrors, but because, 'I hope,' she says, 'that some [of their courage] will rub off on me'. In retelling these stories from her long humanitarian career, she passes some of that courage to her readers. Her beautifully weft stories of a lone psychiatrist bearing children's unbearable burdens are beacons of hope to their bomb-shattered childhoods and to our broken world.

Sabina Dosani (D), Consultant Child and Adolescent Psychiatrist, Department of English, Virginia Woolf Building, Kings College London, 22 Kingsway, London WC2B 6NR, UK. Email: sabina.dosani@kcl.ac.uk

\section{Declaration of interest}

In 2014, Jones and I were coincidentally participants on a memoir writing course run by the Guardian Newspaper. We have not remained in contact and she does not know I have read her book.

\section{doi:10.1192/bjb.2019.21}
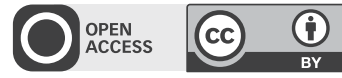

(c) The Author 2019. This is an Open Access article, distributed under the terms of the Creative Commons Attribution licence (http://creativecommons.org/ licenses/by/4.0/), which permits unrestricted re-use, distribution, and reproduction in any medium, provided the original work is properly cited.

\section{Student Mental Health: A Guide for Psychiatrists, Psychologists, and Leaders Serving in Higher Education}

Edited by Laura Weiss Roberts. American Psychiatric Association. 2018. 530 pp. $€ 41.40$ (pb). ISBN 9781615371143

This is a comprehensive resource for professionals working with students in higher education. Subsections of the book address in turn the student experience, caring for students with mental health issues and how to foster mental health in distinct student populations. The book takes an academically robust approach to supporting student self-care, wellbeing and development of resilience.

Individual chapters go on to address key presentations around substance misuse, suicidality, mood and anxiety disorders, psychotic illness, autism, ADHD, trauma, sleep and eating disorders. There is also an important focus upon the role of university mental health services for students who have faced sexual violence, those from military backgrounds and first generation university attenders, as well as students identifying as part of the LGBTQ community. It is in the last chapter where the challenges for 'medical students, residents and fellows' are explored, albeit somewhat briefly. The writers identify the unique stressors for this group and reflect upon the obstacles to seeking help such as stigma and confidentiality. It is noteworthy that all medical students in the American system are postgraduate and therefore usually older than British students, most of whom enter medical school straight from sixth form/college and are less prepared for the expectations of professionalism at this early stage of their development.

Although written from the perspective of the American educational system, in general the content is still eminently transferrable to UK institutions. Throughout the book, its contributors make few assumptions as to prior knowledge, detailing everything from the risk-taking behaviours that develop during 'emerging adulthood' to the descriptive psychopathology for different major mental illnesses. Each chapter's utilisation of 'key concept' bullet points and case examples further increase its accessibility to the reader.

Ultimately the book makes recommendations not only on how student health programmes can achieve excellence by successfully managing students with major mental illness, but also on how all students can be supported to reach their full potential. It is a valuable resource for teachers in higher education.

Catherine Marshall, Clinical Lecturer in Psychiatry, Centre for Psychiatry, Queen Mary University of London, UK; Ania Korszun, Professor of Psychiatry and Education, Barts and The London School of Medicine and Dentistry, Queen Mary University of London, UK. Email: a.korszun@qmul. ac.uk

doi:10.1192/bjb.2019.22

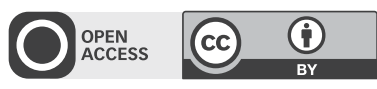

(c) The Authors 2019. This is an Open Access article, distributed under the terms of the Creative Commons Attribution licence (http://creativecommons.org/ licenses/by/4.0/), which permits unrestricted re-use, distribution, and reproduction in any medium, provided the original work is properly cited.

\section{The Whisperer}

By Karin Fossum

Harvill Secker Imprint. 2018. E12.99 (pb). 384 pp. ISBN 9781787300941

How can we understand psychosis without experiencing it ourselves? How can we convey such a complex, bizarre and (as Jaspers would have it) un-understandable experience to others, particularly those new to psychiatry? It is a difficult task.

Karin Fossum, the respected Norwegian crime writer, does not shy away from confronting the more unpalatable aspects of the human mind. Her portfolio has included an exploration of the psychological motivation of paedophiles, elder abusers, and vulnerable people who are drawn into crime. Her focus is not on what, but why. 